\title{
APLIKASI SURFAKTAN MINYAK SAWIT UNTUK PROSES PEMASAKAN-PENGELANTANGAN DAN PENCELUPAN TEKSTIL
}

\author{
THE APPLICATION OF PALM OIL SURFACTANTS FOR TEXTILE SCOURING- \\ BLEACHING AND DYEING
}

\author{
Arif Wibi Sana, Zubaidi \\ Balai Besar Tekstil, \\ Jl. Jenderal Ahmad Yani 390. Bandung \\ E-mail: texirdti@bdg.centrin.net.id
}

Tanggal diterima : 22 Maret 2017, direvisi: 4 Oktober 2017, disetujui terbit: 2 November 2017

\begin{abstract}
ABSTRAK
Minyak sawit memiliki potensi yang besar untuk ditingkatkan nilai tambahnya melalui pengubahan menjadi surfaktan. Surfaktan berbasis minyak nabati bersifat mudah terurai (biodegradable) sehingga lebih ramah lingkungan. Surfaktan yang dapat disintesis dari minyak sawit diantaranya adalah MES (metil ester sulfonat) dan DEA (dietanol amida). Tujuan dari penelitian ini adalah untuk mengetahui sejauh mana surfaktan dari minyak sawit dapat diterapkan dalam proses basah tekstil. Dalam penelitian ini, surfaktan minyak sawit yaitu MES 1, MES 2, dan DEA, serta surfaktan komersil pembanding diobservasi secara visual serta diuji nilai pH dan waktu pembasahannya. Kemudian masing-masing sampel diaplikasikan dalam proses pemasakan-pengelantangan secara simultan (scouring-bleaching) serta pencelupan (dyeing) kain kapas, rayon, dan poliester. Kain hasil proses diuji daya serap kain, derajat putih, kekuatan tarik, kekuatan warna, beda warna (dE), serta ketahanan luntur terhadap pencucian dan gosokan. Hasil pengujian menunjukan bahwa kekuatan tarik ketiga jenis kain mengalami penurunan sebesar 3\% $26 \%$ setelah proses scouring-bleaching. Hasil pengujian setelah proses dyeing menunjukan bahwa nilai paling baik diperoleh pada kain yang diproses dengan MES 2 (daya serap kain 0,47 detik; derajat putih 72,02; dan kekuatan warna $120,23 \%$ ) sedangkan nilai beda warna yang paling baik diperoleh pada kain yang diproses dengan MES 1 (dE $=0,09$ ). Hasil pengujian ketahanan luntur warna terhadap pencucian serta gosokan kering dan basah menunjukan hasil yang baik untuk semua jenis surfaktan (nilai 4-5). Bila dibandingkan dengan surfaktan pembanding berbasis minyak bumi, surfaktan minyak sawit berpotensi sebagai alternatif surfaktan pengganti.
\end{abstract}

Kata kunci: DEA, MES, minyak sawit, surfaktan

\begin{abstract}
Palm Oil has a great potency to be increased at its added value through conversion to become surfactant. Vegetable oil-based surfactants have biodegradable characteristic so that more eco-friendly. MES (methyl ester sulphonate) and DEA (diethanol amide) are some surfactants which can be synthesized from palm oil. The purpose of this study was to determine the extent of palm oil surfactant can be applied in textile wet processes. In this study, the palm oil surfactant i.e., MES 1, MES 2, DEA, and commercial surfactant comparator were visually observed and tested for its $\mathrm{pH}$ value and wetting time. Then each sample was applied in simultaneous scouring-bleaching and dyeing process of cotton, rayon, and polyester fabric. Processed fabric were tested in absorption, whiteness index, tensile strength, color strength, color difference, as well as color fastness to washing and rubbing. The test results showed that the tensile strength of 3 type of fabric decreased by 3\% to 26\% after scouring-bleaching process. Test results after dyeing process showed that the best values were obtained at fabric processed with MES 2 (absorbency of fabric 0.47 seconds, whiteness index 72.02, and color strength 120.23\%) while the best color difference values were obtained at fabric processed with MES $1(\triangle E=0.09)$. The test results of color fastness to washing as well as dry and wet rubbing showed good results for all surfactant types (grade 4 - 5). Palm oil surfactant is very potential as an alternative product in textile processes when compared to commercial petroleum base surfactants.
\end{abstract}

Keywords: DEA, MES, palm oil, surfactant 


\section{PENDAHULUAN}

Indonesia merupakan produsen minyak sawit utama di dunia dengan jumlah produksi pada tahun 2014 mencapai 31,5 juta ton. ${ }^{1}$ Minyak sawit dapat ditingkatkan nilai tambahnya sekitar 70$80 \%$, yaitu melalui proses pengubahan menjadi surfaktan. Pada tahun 2004, permintaan surfaktan dunia sebesar 11,82 juta ton per tahun dengan peningkatan rata-rata $3 \%$ per tahun.,3 Produksi surfaktan dari bahan baku kelapa sawit prospeknya sangat cerah di Indonesia. Saat ini, dari 95.000 ton kebutuhan surfaktan Indonesia per tahun, sekitar 45.000 ton masih diimpor.

Dewasa ini, isu lingkungan menjadi sangat sensitif. Pencemaran lingkungan akibat limbah proses basah tekstil (wet processing) menjadi masalah yang krusial sehingga dunia industri pun dituntut untuk selektif dalam memilih bahan baku dan semakin peduli terhadap lingkungannya. Bahan yang ramah lingkungan menjadi pilihan alternatif, tidak terkecuali dalam memilih bahan aditif dan surfaktan.

Surfactants atau surface active agents merupakan senyawa aktif yang dapat menurunkan tegangan permukaan dan tegangan antarmuka yang dapat diproduksi melalui sintesis kimiawi maupun biokimiawi. Karakteristik utama surfaktan adalah bersifat ampifilik yaitu senyawa yang memiliki dua gugus yang berlainan sifat dalam satu molekulnya, yaitu gugus polar yang bersifat hidrofilik dan non polar yang bersifat hidrofobik sehingga mampu menyatukan dua bahan yang berbeda kepolarannya. Kegunaannya antara lain sebagai deterjen, zat pembasah, perata, pendispersi, dan pengemulsi. Surfaktan dikelompokkan menjadi empat kelompok berdasarkan gugus hidrofiliknya yaitu surfaktan anionik, kationik, amfoterik, dan nonionik. Jenis yang paling banyak digunakan adalah anionik dan nonionik. ${ }^{4,5}$ Pada umumnya surfaktan diproduksi dari minyak bumi sehingga bersifat tidak dapat diperbaharui serta kurang ramah terhadap lingkungan. ${ }^{6,7,8,9}$ Salah satu alternatif pembuatan surfaktan untuk proses tekstil adalah menggunakan minyak sawit sebagai bahan bakunya.

Kelapa sawit menghasilkan dua macam minyak nabati yang berlainan sifatnya, yaitu minyak yang berasal dari sabut (mesokarp), dikenal dengan crude palm oil (CPO) dan minyak yang berasal dari biji (kernel), dikenal dengan sebutan minyak inti sawit atau palm kernel oil (PKO). ${ }^{5}$ Surfaktan MES merupakan surfaktan anionik yang dibuat dengan menggunakan bahan baku fraksi stearin dari minyak sawit. Stearin sawit merupakan fraksi padat yang dihasilkan dari fraksinasi CPO setelah melalui pemurnian. ${ }^{5}$ Surfaktan MES bersifat lebih ramah lingkungan bila dibandingkan dengan Linier Alkil Benzen Sulfonat/LAS (surfaktan anionik yang dibuat dari bahan minyak bumi) ${ }^{\mathbf{1 0 , 1 1 , 1 2}}$ Selain itu MES bersifat terbarukan dan mengandung antioksidan karoten sehingga memiliki kestabilan oksidatif, dapat terserap dengan baik dalam air, memiliki kelarutan yang tinggi, tidak terpengaruh oleh kesadahan air, kemampuan deterjensi yang lebih baik pada bahan kapas dan poliester, kaya akan kandungan asam lemak $\mathrm{C}_{16}$ dan $\mathrm{C}_{18}$ serta toleran terhadap ion $\mathrm{Ca}^{5,13}$<smiles>[R]C(C(=O)OC)[S+]([O])([O-])O</smiles>

Gambar 1. Struktur kimia MES

Surfaktan DEA merupakan surfaktan nonionik yang dibuat dengan menggunakan bahan baku asam laurat. Bahan tersebut diperoleh dari fraksinasi minyak inti sawit (PKO). Dietanol amida merupakan salah satu surfaktan alkanol amida yang paling penting. Dietanol amida berfungsi sebagai bahan penstabil dan pengembang busa. ${ }^{5}$<smiles>C[14CH2][14CH2]C(=O)N(CCO)CCO</smiles>

Gambar 2. Struktur kimia DEA

Pada tahun 2004, Erliza Hambali dkk meneliti tentang pemanfaatan surfaktan minyak sawit sebagai oil well stimulant agent untuk meningkatkan produksi sumur minyak bumi. ${ }^{14}$ Tahun 2013 penelitian dilanjutkan dengan pengembangan teknologi surfaktan MES untuk aplikasi (Enhanced Oil Recovery/EOR). ${ }^{5}$ Penelitian serupa banyak dilakukan pada tahun sebelumnya dan tahun berikutnya, namun penelitian tentang aplikasi surfaktan nabati berbahan dasar minyak sawit untuk proses basah tektil tidak banyak ditemukan. Berdasarkan pertimbangan tersebut, penulis melakukan penelitian dengan tujuan untuk mengetahui sejauh mana surfaktan dari minyak bumi dapat diterapkan dalam proses basah tekstil, terutama dalam proses scouring-bleaching dan dyeing, sehingga kedepannya diharapkan dapat dimanfaatkan sebagai bahan alternatif pengganti surfaktan komersil yang terbuat dari minyak bumi. 


\section{METODE}

\section{Bahan yang digunakan}

Kain tenun kapas dan rayon diperoleh dari PT. Kusumahadi Textile sedangkan poliester diperoleh dari PT. Sipatex. Surfaktan komersil pembanding yang digunakan adalah teepol dan stamol (khusus untuk dyeing poliester). Surfaktan minyak sawit yang digunakan adalah MES 1 (metil ester sulfonat) dan DEA (dietanol amida), diperoleh dari dari SBRC - IPB (Surfactant and Bionergy Research Center-Institut Pertanian Bogor) serta MES 2, diperoleh dari CV. Agroraya Indonesia (distributor PT. Willmar Nabati Indonesia). $\mathrm{H}_{2} \mathrm{O}_{2} 35 \%$ dan $\mathrm{NaOH} 38^{\circ}$ Be diperoleh dari Bratachem. Zat warna reaktif yang digunakan adalah C.I. Reactive Blue 19 dan C.I. Reactive Red 120 (DyStar) sedangkan zat warna dispersi menggunakan C.I. Disperse Yellow 64 (DyStar).

\section{Peralatan}

Peralatan gelas, neraca teknis, bak perendaman kain, pengaduk, mesin lab. dyeing, mesin lab. padding, mesin lab. stenter, mesin cuci, mesin pengering, stopwatch, termometer, dan $\mathrm{pH}$ meter.

\section{Pengujian}

Sebelum proses tekstil : penampakan visual, $\mathrm{pH}$ larutan sesuai dengan ASTM E70-2007, ${ }^{15}$ wetting time (waktu pembasahan) sesuai dengan AATCC TM 17-2005. ${ }^{16}$ Setelah proses tekstil : daya serap bahan sesuai dengan SNI 0279-2013, ${ }^{17}$ derajat putih sesuai dengan AATCC TM 110$2005,{ }^{18}$ kekuatan tarik sesuai dengan ASTM D 5035 - 2011,19 ketuaan warna sesuai dengan AATCC evaluation procedure $6,{ }^{20}$ beda warna sesuai dengan ISO 105 J03-2010, ${ }^{21}$ ketahanan luntur warna terhadap pencucian sesuai dengan SNI ISO 105 - C04 : 2010, ${ }^{21}$ dan ketahanan luntur warna terhadap gosokan sesuai dengan SNI ISO 105 - X12 : 2. ${ }^{23}$ Diagram alir penelitian diperlihatkan pada Gambar 3.

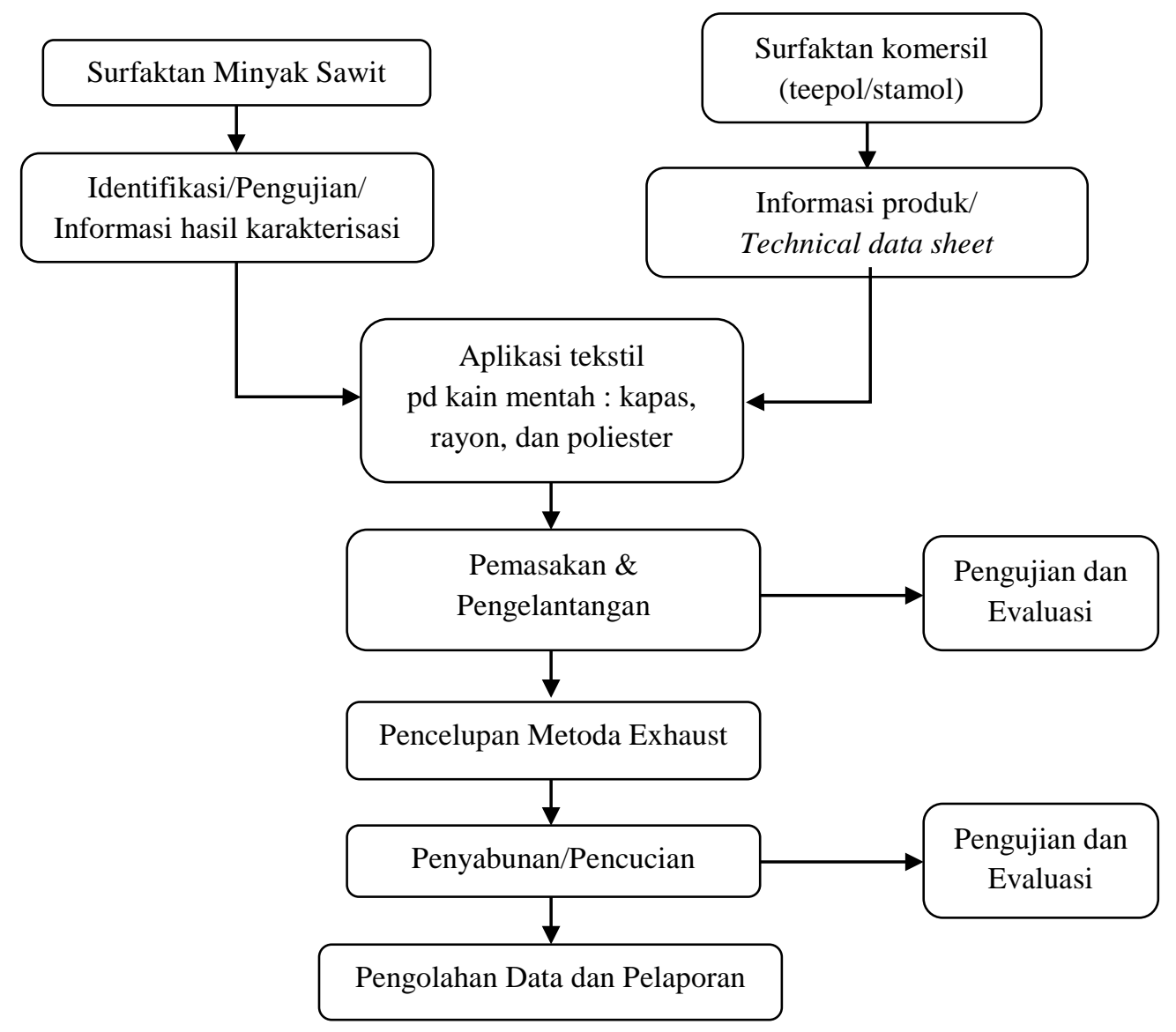

Gambar 3. Diagram alir tahapan penelitian 


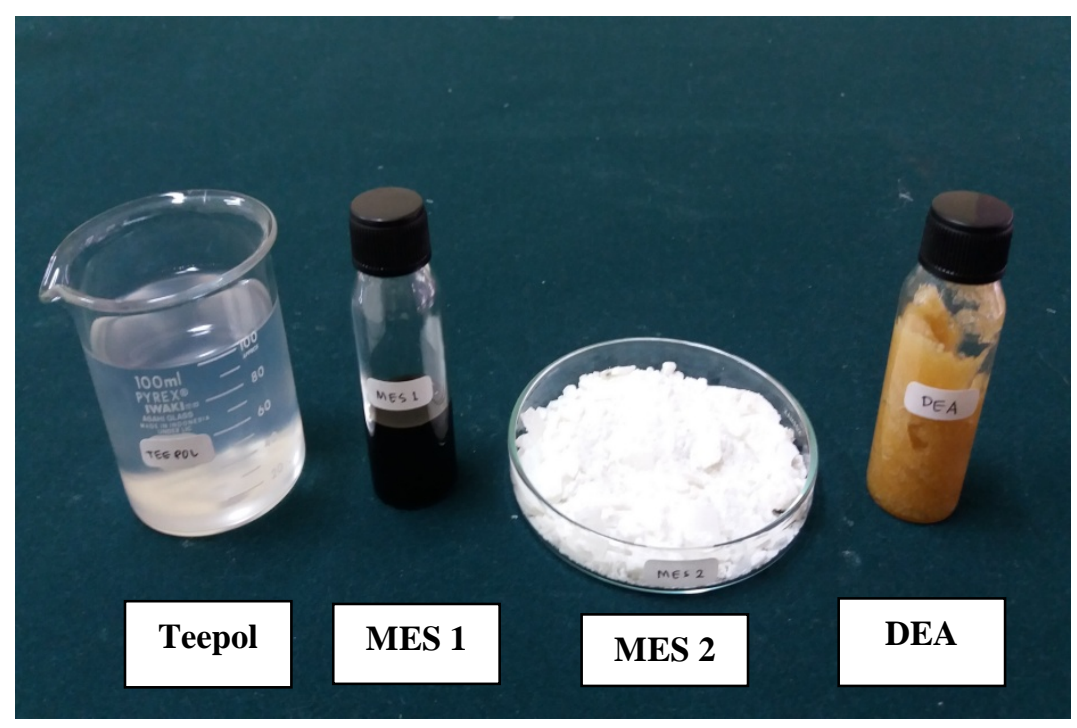

Gambar 4. Sampel surfaktan sebelum dilarutkan

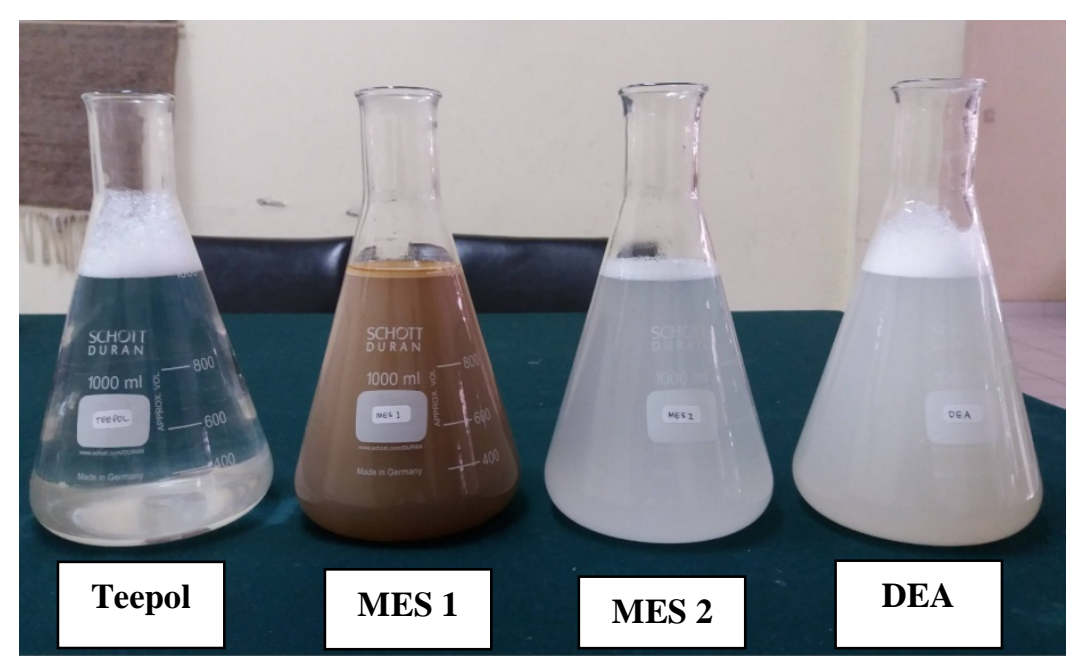

Gambar 5. Sampel surfaktan sesudah dilarutkan

\section{HASIL DAN PEMBAHASAN}

Untuk mengetahui sejauh mana performa surfaktan, semua sampel baik surfaktan minyak sawit maupun surfaktan komersil pembanding diuji baik sebelum maupun sesudah aplikasi pada proses basah tekstil. Pengujian sebelum aplikasi meliputi observasi visual, pengukuran $\mathrm{pH}$ larutan, dan waktu pembasahan (wetting time). Sedangkan pengujian setelah aplikasi meliputi uji daya serap (wettability), derajat putih (whiteness index), dan kekuatan tarik pada kain hasil proses pemasakanpengelantangan (scouring-bleaching) simultan serta uji kekuatan warna, beda warna, ketahanan luntur terhadap pencucian dan gosokan pada kain hasil proses pencelupan (dyeing).

Dari hasil pengukuran $\mathrm{pH}$ larutan yang disajikan pada tabel 1 diketahui bahwa surfaktan komersil dan MES 1 bersifat asam, sedangkan DEA bersifat basa. Adapun MES 2 bersifat netral. Kemungkinan hal ini dapat disebabkan karena 44
MES 1 dan DEA belum mengalami proses netralisasi sehingga nilai $\mathrm{pH}$ tidak mendekati 7.

Waktu pembasahan (wetting time) menunjukan kemampuan surfaktan dalam menurunkan tegangan permukaan, makin kecil atau makin cepat nilai wetting time maka makin mudah suatu bahan terserap/tercelup. Dari hasil pengujian wetting time yang disajikan pada Tabel 2 diketahui bahwa surfaktan teepol memiliki wetting time yang paling cepat $(16,883$ detik) sedangkan surfaktan MES 2 memiliki wetting time yang paling lambat $(104,183$ detik). Nilai wetting time surfaktan MES 2 dan DEA tidak jauh berbeda, namun bila dibandingkan dengan kedua surfaktan tersebut, MES 1 memiliki wetting time lebih baik walaupun belum sebaik surfaktan komersil.

Pengujian kekuatan tarik kain (tensile strength) dilakukan untuk mengetahui sejauh mana proses basah tekstil berpengaruh terhadap sifat 
fisik kain. Hasil pengujian yang diperlihatkan dalam Tabel 1 menunjukan bahwa kekuatan tarik kain mengalami penurunan setelah proses scouring-bleaching untuk semua jenis surfaktan. Pada kain kapas, penurunan yang signifikan diperoleh pada kain yang diproses dengan surfaktan MES 2 (23\%) sementara pada kain rayon, penurunan yang signifikan diperoleh pada kain yang diproses dengan surfaktan MES 1 (26\%). Adapun kain poliester tidak mengalami penurunan kekuatan tarik. Proses scouringbleaching secara simultan menggunakan $\mathrm{NaOH}$ sebagai zat pemasak (scouring agent) dan hidrogen peroksida sebagai zat pengelantang (bleaching agent). Scouring agent berfungsi untuk menyabunkan sisa minyak, menetralkan asam karboksilat, melarutan zat penganji, dan mendispersikan kotoran alami pada serat alam. Dalam proses scouring-bleaching, surfaktan dapat berfungsi ganda sebagai zat pembasah dan scouring agent. Penurunan kekuatan tarik pada kain berbasis serat selulosa seperti kapas dan rayon dapat dijelaskan berdasarkan mekanisme proses bleaching.

$$
\begin{gathered}
\mathrm{H}_{2} \mathrm{O}_{2} \longleftrightarrow \mathrm{H}^{+}+\mathrm{HO}_{2}^{-} \\
\mathrm{H}_{2} \mathrm{O}_{2} \longrightarrow \mathrm{H}^{+}+\mathrm{HO}_{2}^{-} \stackrel{\mathrm{OH}^{-}}{\longrightarrow} \mathrm{HO}_{2}^{-}+\mathrm{H}_{2} \mathrm{O}
\end{gathered}
$$

Hidrogen peroksida stabil dalam suasana asam, namun proses pemutihan/pengelantangan (bleaching) terjadi karena adanya penambahan alkali atau kenaikan suhu. Hidrogen peroksida membebaskan ion perhidroksil $\left(\mathrm{HO}_{2}^{-}\right)$dalam media cair dan secara kimia berperilaku seperti asam lemah. Perhidroksil sangat tidak stabil dan apabila bertemu dengan suatu zat yang dapat teroksidasi (noda berwarna pada kain selulosa), maka noda tersebut akan terdekomposisi sehingga terjadi proses pemutihan. Pada proses scouringbleaching secara simultan, $\mathrm{NaOH}$ akan mengaktivasi hidrogen peroksida karena ion $\mathrm{H}^{+}$ dinetralkan oleh alkali, dimana kondisi tersebut lebih dipilih dalam pembebasan $\mathrm{HO}_{2}^{-}$. Namun pada $\mathrm{pH}$ yang sangat tinggi (lebih dari 10,8), pembebasan ion $\mathrm{HO}_{2}^{-}$terjadi begitu cepat sehingga menjadi tidak stabil dan membentuk gas oksigen yang tidak memiliki sifat memutihkan. Bila kecepatan dekomposisi terlalu tinggi ion $\mathrm{HO}_{2}{ }^{-}$ yang tidak terpakai dapat merusak serat, akibatnya kekuatan tarik kain menurun. $\mathrm{pH}$ yang aman dan optimum untuk proses bleaching serat selulosa terletak antara 10,5 10,8 dimana kecepatan evolusi ion perhidroksil sama dengan kecepatan yang diperlukan untuk mendekomposisi noda. ${ }^{24}$

Derajat putih (whiteness index) dapat dijadikan satu tolak ukur untuk menilai sejauh mana efektifitas proses persiapan penyempurnaan (pre-treatment) suatu bahan dalam hal ini scouring-bleaching secara simultan pada kain kapas dan rayon, serta scouring-relaxing pada kain poliester. Makin tinggi nilai whiteness index, makin putih penampakan suatu bahan. Dari hasil pengujian whiteness index yang disajikan pada tabel 1 diketahui bahwa untuk semua jenis kain baik kapas, rayon, maupun poliester dan semua jenis surfaktan memiliki nilai yang saling mendekati, namun nilai WI yang paling menonjol diperoleh pada surfaktan MES 2 dengan nilai secara berturut-turut adalah 70,11; 71,57; dan 72,57. Ini membuktikan bahwa surfaktan minyak sawit memiliki kemampuan yang sama baiknya dengan surfaktan komersil dalam membantu proses scouring-bleaching.

Daya serap kain (wettability) menunjukan kemampuan surfaktan dalam membantu penyerapan terhadap suatu bahan, makin cepat nilai wettability maka daya serap terhadap bahan semakin baik. Dari hasil pengujian wettability yang disajikan pada tabel 1diketahui bahwa pada kain kapas, surfaktan MES 1 memiliki nilai paling baik (10,600 detik) sedangkan pada kain rayon, surfaktan MES 2 memiliki nilai paling baik (0,456 detik) walaupun nilainya tidak jauh berbeda dengan nilai yang ditunjukan oleh teepol, MES 1, dan DEA. Adapun pada kain poliester, nilai yang paling baik ditunjukan oleh kain mentah (3,2 detik). Proses scouring menggunakan alkali lemah dan variasi surfaktan pada kain poliester menyebabkan penyerapan kain lebih lambat. Nilai paling buruk ditunjukan oleh teepol dan MES 1 dimana waktu penyerapan lebih dari 5 menit. Fenomena tersebut kemungkinan disebabkan oleh $\mathrm{pH}$ larutan teepol dan MES 1 yang bersifat asam dimana masing-masing surfaktan memiliki nilai pH 5,74 dan 5,00. Perlu diadakan penelitian lebih lanjut tentang efektifitas kerja surfaktan untuk mengetahui kemungkinan penyebab fenomena dari hasil uji tersebut.

Kekuatan warna (color strength) menunjukan sejauh mana zat warna dapat terserap oleh bahan. Salah satu fungsi dari surfaktan adalah sebagai zat pembasah (wetting agent). Surfaktan yang terbuat dari minyak sawit mempunyai nilai HLB sekitar 7 sampai dengan 9. Berdasarkan tabel kegunaan HLB, nilai tersebut menunjukan bahwa surfaktan minyak sawit memenuhi syarat sebagai zat pembasah. Fungsi dari zat pembasah adalah menurunkan tegangan permukaan sehingga larutan celup lebih mudah berpenetrasi ke dalam bahan. ${ }^{25}$ Tabel 3 menyajikan data hasil uji kekuatan warna kain kapas dan rayon yang dicelup zat warna reaktif dengan variasi penambahan surfaktan MES 1, MES 2, DEA, dan teepol serta kain poliester 
yang dicelup zat warna dispersi dengan variasi penambahan surfaktan MES 1, MES 2, DEA, dan tamol. Pembanding/standar yang digunakan adalah kain yang dicelup tanpa surfaktan. Hasil pengujian menunjukan bahwa pada kain kapas dan poliester, kekuatan warna paling tinggi diperoleh pada kain yang diproses dengan surfaktan MES 2 (120,23\% dan 106,95 \%) sedangkan pada kain rayon, kekuatan warna paling tinggi diperoleh pada kain yang diproses dengan surfaktan MES 1 (108,31 $\%)$. Kekuatan warna yang paling rendah diperoleh pada surfaktan DEA pada pencelupan kapas dan rayon dengan zat warna reaktif (29,94 \% dan 35,97 $\%)$. Perlu diadakan penelitian lebih lanjut tentang efektifitas kerja surfaktan untuk mengetahui kemungkinan penyebab fenomena dari hasil uji tersebut.

Pengujian beda warna (color difference) dilakukan untuk mengetahui sejauh mana perbedaan hasil pencelupan dengan target. Dalam pengujian ini, kain yang diproses dengan surfaktan komersil dijadikan sebagai target.

Tabel 1. Hasil pengujian sebelum scouring-bleaching

\begin{tabular}{|c|c|c|c|c|}
\hline Parameter Uji & Teepol & MES 1 & MES 2 & DEA \\
\hline Fasa & cairan kental & cairan encer & serbuk & pasta \\
\hline Warna & tak berwarna & coklat kehitaman & putih & coklat muda \\
\hline $\mathrm{pH}$ & 5,74 & 5,00 & 6,95 & 8,38 \\
\hline Wetting time (detik) & 16,883 & 54,646 & 104,183 & 102,265 \\
\hline
\end{tabular}

Tabel 2. Hasil pengujian setelah proses scouring-bleaching

\begin{tabular}{|c|c|c|c|c|c|c|c|c|}
\hline \multirow[b]{2}{*}{ Parameter Uji } & \multirow{2}{*}{\multicolumn{2}{|c|}{ Jenis Kain }} & \multirow{2}{*}{$\begin{array}{c}\text { Kain } \\
\text { Mentah }\end{array}$} & \multicolumn{5}{|c|}{ Proses Scouring-Bleaching } \\
\hline & & & & $\begin{array}{c}\text { Tanpa } \\
\text { surfaktan }\end{array}$ & $\begin{array}{c}+ \\
\text { Teepol }\end{array}$ & $\begin{array}{c}+ \\
\text { MES } 1\end{array}$ & $\stackrel{+}{\stackrel{+}{M E S} 2}$ & $\begin{array}{c}+ \\
\text { DEA }\end{array}$ \\
\hline \multirow{6}{*}{$\begin{array}{l}\text { Kekuatan tarik / } \\
\text { tensile strength } \\
\text { (N) }\end{array}$} & \multirow{2}{*}{ Kapas } & Arah Lusi & 287,806 & 242,891 & 242,420 & 239,969 & 222,336 & 230,260 \\
\hline & & Arah Pakan & 222,121 & 184,326 & 187,778 & 194,760 & 185,954 & 182,257 \\
\hline & \multirow{2}{*}{ Rayon } & Arah Lusi & 176,010 & 138,862 & 139,137 & 130,625 & 137,019 & 140,667 \\
\hline & & Arah Pakan & 99,381 & 88,907 & 88,015 & 86,838 & 89,044 & 96,576 \\
\hline & \multirow{2}{*}{ Poliester } & Arah Lusi & 362,493 & 387,892 & 376,693 & 382,283 & 373,810 & 363,101 \\
\hline & & Arah Pakan & 264,427 & 302,025 & 295,690 & 281,392 & 286,276 & 276,057 \\
\hline \multirow{3}{*}{$\begin{array}{l}\text { Derajat putih / } \\
\text { whiteness index }\end{array}$} & Kapas & & 13,09 & 63,66 & 69,91 & 68,33 & 70,11 & 68,46 \\
\hline & Rayon & & 5,7 & 67,75 & 69,34 & 68,61 & 71,57 & 66,31 \\
\hline & Poliester & & 67,42 & 67,8 & 68,67 & 64,05 & 72,02 & 64,72 \\
\hline \multirow{3}{*}{$\begin{array}{l}\text { Daya serap kain / } \\
\text { wettability } \\
\text { (detik) }\end{array}$} & Kapas & & $>5 \min$ & $>5 \min$ & 15,900 & 10,600 & 90,600 & 24,800 \\
\hline & Rayon & & 21,000 & 0,689 & 0,600 & 0,536 & 0,456 & 0,553 \\
\hline & Poliester & & 3,200 & 138,508 & $>5 \min$ & $>5 \min$ & 176,800 & 34,800 \\
\hline
\end{tabular}

Tabel 3. Hasil pengujian setelah proses dyeing

\begin{tabular}{|c|c|c|c|c|c|}
\hline \multirow{3}{*}{ Parameter Uji } & \multirow{3}{*}{ Jenis Kain } & \multicolumn{4}{|c|}{ Proses Dyeing } \\
\hline & & + & + & + & + \\
\hline & & Teepol/Stamol* & MES 1 & MES 2 & DEA \\
\hline \multirow{3}{*}{$\begin{array}{l}\text { Kekuatan warna } \\
\text { / color strength } \\
\text { (\%) }\end{array}$} & Kapas & 110,85 & 113,45 & 120,23 & 29,94 \\
\hline & Rayon & 100,61 & 108,31 & 93,96 & 35,97 \\
\hline & Poliester* & 101,88 & 103,15 & 106,95 & 103,69 \\
\hline \multirow{3}{*}{$\begin{array}{l}\text { Beda warna } \\
\text { (color difference) }\end{array}$} & Kapas & - & 0,29 & 0,68 & 8,38 \\
\hline & Rayon & - & 0,36 & 0,47 & 6,41 \\
\hline & Poliester* & - & 0,09 & 0,71 & 0,87 \\
\hline
\end{tabular}

Untuk pencelupan kain kapas dan rayon, teepol digunakan sebagai surfaktan pembanding sedangkan pencelupan kain poliester menggunakan stamol. Tabel 3 juga menyajikan data hasil uji beda warna kain kapas dan rayon yang dicelup zat warna reaktif dengan variasi penambahan surfaktan MES 1, MES 2, DEA, dan teepol serta kain poliester yang dicelup zat warna dispersi dengan variasi penambahan surfaktan MES 1, MES 2, DEA, dan tamol. Pembanding/standar yang digunakan adalah kain yang dicelup dengan teepol/stamol. Hasil pengujian menunjukan bahwa surfaktan MES 1 dan 2 yang diaplikasikan dalam pencelupan semua jenis kain memiliki nilai beda warna yang baik (< 1 ), beda warna yang paling baik diperoleh pada 
kain yang diproses dengan surfaktan MES $1(0,29$; 0,36; dan 0,09). Beda warna yang paling buruk diperoleh pada pencelupan kain kapas dan rayon dengan surfaktan DEA dengan nilai beda warna $>1$ (8,38 dan 6,41). Seperti halnya dalam kekuatan warna, beda warna juga ditentukan oleh banyaknya zat warna yang terfiksasi. Perlu diadakan penelitian lebih lanjut tentang efektifitas kerja surfaktan untuk mengetahui kemungkinan penyebab fenomena dari hasil uji tersebut.

Tahan luntur warna merupakan salah satu parameter yang sangat penting untuk menentukan kualitas hasil pencelupan. Hasil pengujian pada tabel 4 menunjukan bahwa tahan luntur warna terhadap pencucian untuk semua jenis kain, baik yang dicelup dengan bantuan surfaktan komersil maupun surfaktan minyak sawit, mempunyai nilai yang baik (4-5).

Tabel 5 menyajikan hasil pengujian tahan luntur warna terhadap gosokan baik kering maupun basah. Hail uji tahan luntur warna terhadap gosokan kering untuk semua jenis kain, baik yang dicelup dengan bantuan surfaktan komersil maupun surfaktan minyak sawit, mempunyai nilai yang baik (4-5) sementara untuk gosokan basah nilainya cukup baik (4). Adapun nilai yang paling baik diperoleh pada kain yang diproses dengan bantuan surfaktan DEA. Hal ini dapat dipahami bahwa hasil pencelupan dengan surfaktan DEA memiliki warna yang paling muda dibandingkan dengan surfaktan lain sehingga warna yang terkikis oleh gosokan pun relatif lebih sedikit.

Tabel 4. Hasil pengujian tahan luntur warna terhadap pencucian

\begin{tabular}{rlccccc}
\hline \multirow{2}{*}{$\begin{array}{c}\text { Jenis } \\
\text { Kain }\end{array}$} & $\begin{array}{c}\text { Pelapis } \\
\text { (Multifiber) }\end{array}$ & $\begin{array}{c}\text { Tanpa } \\
\text { Surfaktan }\end{array}$ & Teepol & MES 1 & MES 2 & DEA \\
\cline { 2 - 6 } Kapas & Asetat & $4-5$ & $4-5$ & $4-5$ & $4-5$ & $4-5$ \\
& Kapas & $4-5$ & $4-5$ & $4-5$ & $4-5$ & $4-5$ \\
& Nilon & $4-5$ & $4-5$ & $4-5$ & $4-5$ & $4-5$ \\
& Poliester & $4-5$ & $4-5$ & $4-5$ & $4-5$ & $4-5$ \\
& Akrilat & $4-5$ & $4-5$ & $4-5$ & $4-5$ & $4-5$ \\
& Wool & $4-5$ & $4-5$ & $4-5$ & $4-5$ & $4-5$ \\
\hline \multirow{6}{*}{ Rayon } & Asetat & $4-5$ & $4-5$ & $4-5$ & $4-5$ & $4-5$ \\
& Kapas & $4-5$ & $4-5$ & $4-5$ & $4-5$ & $4-5$ \\
& Nilon & $4-5$ & $4-5$ & $4-5$ & $4-5$ & $4-5$ \\
& Poliester & $4-5$ & $4-5$ & $4-5$ & $4-5$ & $4-5$ \\
& Akrilat & $4-5$ & $4-5$ & $4-5$ & $4-5$ & $4-5$ \\
& Wool & $4-5$ & $4-5$ & $4-5$ & $4-5$ & $4-5$ \\
\hline \multirow{6}{*}{ Poliester } & Asetat & $4-5$ & $4-5$ & $4-5$ & $4-5$ & $4-5$ \\
& Kapas & $4-5$ & $4-5$ & $4-5$ & $4-5$ & $4-5$ \\
& Nilon & $4-5$ & $4-5$ & $4-5$ & $4-5$ & $4-5$ \\
& Poliester & $4-5$ & $4-5$ & $4-5$ & $4-5$ & $4-5$ \\
& Akrilat & $4-5$ & $4-5$ & $4-5$ & $4-5$ & $4-5$ \\
& Wool & $4-5$ & $4-5$ & $4-5$ & $4-5$ & $4-5$ \\
\hline
\end{tabular}

Tabel 5. Hasil pengujian tahan luntur warna terhadap gosokan

\begin{tabular}{rlccccc}
\hline \multirow{2}{*}{$\begin{array}{c}\text { Jenis } \\
\text { Kain }\end{array}$} & \multirow{2}{*}{ Gosokan } & $\begin{array}{c}\text { Tanpa } \\
\text { Surfaktan }\end{array}$ & Teepol & MES 1 & \multirow{2}{*}{ MES 2 } & \multirow{2}{*}{ DEA } \\
\cline { 3 - 7 } Kapas & Kering & $4-5$ & $4-5$ & $4-5$ & $4-5$ & $4-5$ \\
& Basah & 4 & 4 & 4 & 4 & $4-5$ \\
\hline \multirow{2}{*}{ Rayon } & Kering & $4-5$ & $4-5$ & $4-5$ & $4-5$ & $4-5$ \\
& Basah & 4 & 4 & 4 & 4 & $4-5$ \\
\hline \multirow{2}{*}{ Poliester } & Kering & $4-5$ & $4-5$ & $4-5$ & $4-5$ & $4-5$ \\
& Basah & $4-5$ & $4-5$ & $4-5$ & $4-5$ & $4-5$ \\
\hline
\end{tabular}




\section{KESIMPULAN}

Dari penelitian ini dapat disimpulkan bahwa semua sampel surfaktan minyak sawit yang digunakan dalam penelitian dapat diaplikasikan dalam proses basah tekstil seperti pemasakanpengelantangan secara simultan (scouringbleaching) dan proses pencelupan (dyeing), walaupun tingkat efektifitas dari masing-masing surfaktan berbeda-beda. Hasil pengujian menunjukkan bahwa kekuatan tarik kain mengalami penurunan setelah proses scouringbleaching untuk semua jenis surfaktan. Kain yang diproses dengan MES 2 memiliki nilai daya serap kain, derajat putih, dan kekuatan warna yang paling baik sedangkan nilai beda warna yang paling baik diperoleh pada kain yang diproses dengan MES 1. Hasil pengujian ketahanan luntur baik terhadap pencucian maupun gosokan kering dan basah menunjukan hasil yang relatif sama untuk semua jenis surfaktan. Bila dibandingkan dengan MES 1 dan DEA, hasil uji surfaktan MES 2 mempunyai nilai baik yang lebih dominan. Tren hasil uji memperlihatkan bahwa surfaktan dari miyak sawit memiliki potensi untuk dapat menggantikan surfaktan komersil yang terbuat dari minyak bumi dan keberadaannya masih impor.

Perlu diteliti lebih lanjut tentang efektifitas kerja surfaktan dan uji lanjutan dalam bentuk karakterisasi sampel surfaktan, pengujian secara fisika terhadap kain hasil pemasakanpengelantangan dan pencelupan, variasi resep surfaktan minyak sawit untuk mendapatkan kondisi optimum, aplikasi surfaktan minyak sawit dalam proses tekstil yang lain seperti pencapan dan penyabunan, kerjasama dengan SBRC untuk membuat varian surfaktan minyak sawit yang mempunyai nilai HLB yang sesuai dengan beberapa proses tekstil, kerjasama dengan PT. Willmar Nabati Indonesia untuk memproduksi surfaktan minyak sawit dengan karakteristik khusus untuk pasar industri tekstil.

\section{DAFTAR PUSTAKA}

1. Nirwana, Irdoni, dan Jatikta Yuniharti. Sintesis Surfaktan Metil Ester Sulfonat dari Palm Oil Methyl Ester dan Natrium Metabisulfit dengan Penambahan Katalis Kalsium Oksida. Jurnal Riset Kimia. 8 (2), Fakultas Teknik Kimia Universitas Riau, (2015).

2. Purwaningtyas, E.F., \& Pramudono, B., Pembuatan Surfaktan Polyoxyethylene Dari Minyak Sawit: Pengaruh Rasio MonoDigliserida dan Polyethylen Glykol. Reaktor, 12 (3), Hal. 175-182, (2009).

3. Widodo H.S. Seminar Nasional Pemanfaatan Surfaktan Berbasis Minyak Sawit untuk
Industri, Bogor: Dies ke-42 Fakultas Pertanian IPB, (2004).

4. Fan, R.J., Chemistry and Technology of Surfactants. Blackwell Publishing (2006).

5. Hambali,m E.,, Suryani A \& Rivai M. Teknologi Surfaktan dan Aplikasinya. Bogor: IPB Press, (2012).

6. Sulastri, Y., Sintesis Methyl Ester Sulfonic Acid (Mesa) dari Crude Palm Oil (CPO) Menggunakan Single Tube Falling Film Reactor. Bogor: IPB, (2010).

7. Hambali, E., Suryani, A., \& Rivai, M., Proses Pengembangan Teknologi Surfaktan MES dari Metil Ester Minyak Sawit Untuk Aplikasi EOR/IOR: dari Skala Lab Ke Skala Pilot. Bogor: Surfactant \& and Bioenergy Research Center (SBRC), LPPM IPB, (2013).

8. Schramm, L.L., Stasiuk, E.N., \& Marangoni, D.G., Surfactants and Their Applications. Annu. Rep. Prog. Chem., Sect. C, 2003, 99, 348, (2013).

9. Yangxin, Y., Jin, Z., \& Bayly, A.E. Development of Surfactants and Builders in Detergent Formulations, (2008).

10. Zoller, U. Handbook of Detergents, Part F : Production. New York: CRC Press, (2009).

11. Setiyono, L., Kartika, I., \& Nurhidayanti, Surfaktan Metil Ester Sulfonat (MES), Bogor: FTP-IPB, (2009).

12. Trivedi, S.N. Methyl Ester Sulfonates (MES) - An Alternate Surfactant From Renewable Natural Resources. (2005).

13. Martinez, D., Orozco, G., Rincon, S. Simulation and Pre-feasability Analysis of the Production Process of $\alpha$-Methyl Ester Sulphonates. Bioresource Technology. 101, 8762-8771. (2010).

14. Hambali, et.al. Pemanfaatan Surfaktan Ramah Lingkungan dari Minyak Sawit sebagai Oil Well Stimulant Agent untuk Meningkatkan Produksi Sumur Minyak Bumi. Proposal Hibah Kompetisi Pengembangan Masyarakat. Bogor: Departemen Teknologi Industri Pertanian IPB, (2004).

15. ASTM E70-2007, Standard Test Method for $\mathrm{pH}$ of Aqueous Solutions With the Glass Electrode (2007).

16. AATCC TM 17-2005, Wetting Agents (2005). 
17. SNI 0279-2013, Cara Uji Daya Serap Bahan Tekstil. (2013).

18. AATCC TM 110-2005, Whiteness of Textiles. (2005).

19. ASTM D 5035 - 2011, Standard Test Method for Breaking Force and Elongation of Textile Fabrics (Strip Method). (2011)

20. AATCC evaluation Procedure 6, Instrumental Color Measurement.

21. SNI ISO 105-J03 : 2010, Perhitungan Beda Warna. (2010).
22. $\quad$ SNI ISO 105 - C04 : 2010, Ketahanan Luntur Warna Terhadap Pencucian. (2010).

23. SNI ISO 105 - X12 : 2012, Ketahanan Luntur Warna Terhadap Gosokan (2012).

24. S.R. Karmakar. Chemical Technology In The Pre-Treatment Processes of Textiles. Textile Science and Technology 12. (1999).

25. Arthur D Broadbent. Basic Principles of Textile Coloration. Society of Dyers and Colourist. (2001) 
Arena Tekstil Vol. 32 No. 1, 2017,41-50 